\title{
CONSTRUCTIVE ANALYSIS OF MAYA VAULTED ARCHITECTURE FROM PHOTOGRAMMETRIC SURVEY
}

\author{
L. Gilabert-Sansalvador ${ }^{1, *}$, R. Montuori ${ }^{1,2}$, A. L. Rosado-Torres ${ }^{1,2}$ \\ ${ }^{1}$ Universitat Politècnica de València, Camí de Vera s/n 46022 Valencia, Spain - (laugisan, ricmon, anrotor3)@upv.es \\ ${ }^{2}$ Research Centre PEGASO, Universitat Politècnica de València, Valencia, Spain
}

Commission II - WG II/8

KEY WORDS: Uxmal, Vault, Photogrammetry, Digital, Construction, Stonework

\begin{abstract}
:
Studying Maya architecture from a constructive perspective reveals new insights into the ancient building techniques and processes. Gaining deep knowledge of these structures is key to assessing the current conservation state of the buildings and to designing strategies for the excavation and preservation of this heritage. In order to study the Maya vault system, considering its regional variants and technical development over time, we performed field data collections at 48 Maya Lowlands archaeological sites with the aim of documenting and comparing constructive techniques from different areas and chronological periods. Surveying some of these buildings with digital photogrammetry made it possible to obtain geometrically accurate models with a high-quality texture that were used to measure, analyze and compare the features of the vaults in detail. The main advantage of this survey methodology is that it permits to achieve a high amount of information with affordable instruments. From the models obtained, a thorough analysis of stonemasonry techniques, stereotomy solutions and building processes was carried out, considering their implications for the stability and conservation of the structures. This paper presents the survey methodology used and an example of the constructive analysis of a vaulted building from a photogrammetric model.
\end{abstract}

\section{INTRODUCTION}

The ancient Maya civilization developed in Central America, in an area that includes the current countries of Guatemala, Belize, southeast Mexico and parts of Honduras and El Salvador. This geographically heterogeneous territory covers the entire Yucatan peninsula and extends to the Pacific coast. During the Classic Period (250-1000 CE), when the Maya reached their greatest splendor, they planned and built hundreds of cities with magnificent architecture and equipped with urban, water and defensive infrastructures. The political and religious activities took place in the core of these cities, reserved for the elite. In these ceremonial centers the Maya raised monumental temples and palaces built of stone, profusely decorated with stucco reliefs or carved stone mosaics and painted in bright colors to emphasize their symbolic meaning of power.

During the long constructive tradition of Maya architecture, different architectural styles associated with certain geographical areas emerged. Some of them are well known, for instance: the massive architecture of Peten, with pyramidal temples and complex palace acropolis; the architectural style of the Usumacinta river basin sites, as Palenque or Yaxchilan, with slotted roofcombs and elaborated stucco decorations; or the Puuc style, with its characteristic carved stone mosaics. In other stylistic regions, such as Rio Bec or Chenes, the buildings have also their own typological, constructive and decorative features. Although these styles share common principles and some characteristics, the architecture of each region developed its own peculiarities and typical features, so, over time, technical and formal improvements occurred differently in each area.

After the so-called "collapse" of the Maya civilization, which began in the 11th century, the cities went into decline and some of them were abandoned. Over the years, the aggressive natural environment invaded the structures, and many of those remained buried and hidden by the jungle for centuries. It was not until the end of the 19th century that these ancient cities began to arouse the romantic interest of explorers and travelers. Their suggestive drawings and descriptions prompted the first archaeological campaigns as well as the beginning of the scientific study of Maya archaeology.

Maya architecture is nowadays an internationally recognized cultural heritage. Eight Maya cities have been declared World Heritage Sites by UNESCO and many others are being investigated, studied and preserved. The available archaeological and epigraphic data related with the ancient Maya increase every day, allowing us to know more about this ancient culture. However, due to the lack of specialized architectural studies, constructive and structural knowledge of Maya buildings is still scarce, despite the great importance of these issues in assessing the current conservation state of the buildings and establishing appropriate restoration criteria.

This paper presents part of the results of a recently conducted study on the Maya vaulted architecture (Gilabert, 2018b), in which digital documentation was applied for the constructive analysis of this cultural heritage.

\section{AN INVESTIGATION ON MAYA VAULTED ARCHITECTURE}

The vault is one of the most hallmark elements of Maya architecture, since the Maya used this type of stone roof in most of their buildings. The Maya vault system is based on the structural principle of corbeling, which consists of placing stones projecting above one another. A corbeled vault is built up from

\footnotetext{
* Corresponding author
} 
opposing walls advancing in stepped-out courses that progress forward until closing the space with a final course of slabs or capstones. The stability of this system is based on the correct counterbalance of each of the rows, either by its own weight or by a back-filling core that prevents them from overturning. The main advantage of this building technique is that it admits uncut stones. Nevertheless, it requires thick walls and achieves limited spans.

While the Maya initially used this principle of corbeling, eventually they developed a wide range of formal and constructive types of vaults. The eagerness to expand the vault span and therefore the interior spaces, both in width and height, led the Maya builders to develop advanced vaulting techniques that even implied changes in the structural system. Corbeled vaults gradually evolved into monolithic or cast vaults (Hohmann, 1979) with highly specialized vault stones forming the facing of a supporting core of lime concrete. The best example of this second system can be seen in Puuc architecture, which experienced a great technological development of the vaulted construction over time (Figure 1).

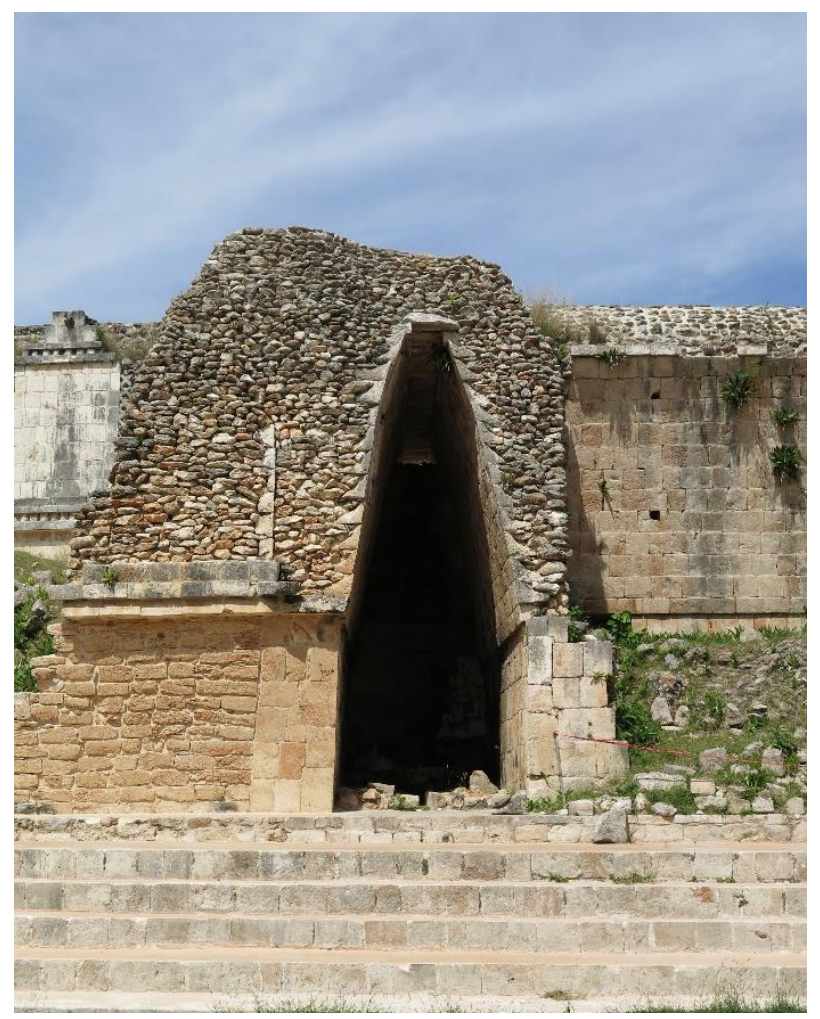

Figure 1. Vault with highly specialized vault stones in the Building 22 of the Puuc site of Uxmal (Yucatan, Mexico).

In order to thoroughly analyze this vault system and to characterize its main regional variants, we conducted an extensive field data collection to document and record the features of a large sample of 391 vaults from different building typologies, geographical areas and chronological periods. For each vault considered, we carried out an exhaustive photographic documentation and filled in a registration form based on observations and direct measurements (Gilabert, 2018b).
In addition, 47 vaults of this sample were documented with digital photogrammetry, which proved to be a very practical technique to obtain high-quality graphic documentation of the vaults, according to the method discussed below. To show an example, we present a case of a vaulted building from the archaeological site of Uxmal, in Yucatan (Mexico).

\section{PHOTOGRAMMETRIC SURVEY}

Digital photogrammetry allows to obtain a 3D textured mesh model of an object from a series of images acquired from different points of view (Remondino, 2014).

This survey technique has several advantages: firstly, it permits to obtain a high amount of information from a data collection that requires less time than the direct traditional survey and, secondly, it can be performed with simple and affordable instruments. Furthermore, post-processing of the data is becoming quicker and easier, since nowadays there are very user-friendly software applications that automatically provide 3D models from a set of photographs.

However, data collection in a photogrammetric survey requires some experience and an appropriate procedure to ensure that the model obtained has the quality required. In our field of study, the main disadvantage of this survey method is that the resultant models are not oriented and do not have metric dimensions ${ }^{1}$. Therefore, it becomes necessary to apply a complementary survey system to orient and scale them (Russo, Manfredini, 2014). Another limitation of this technique is the dependence on natural light, since the camera is a passive sensor (Merlo, Aliperta, 2015), which complicates data collection in dark interior spaces such as most vaulted rooms in Maya buildings.

Despite these limitations, digital photogrammetry becomes an effective, low-cost alternative tool that can provide remarkably accurate 3D models when a more specialized equipment, such as a laser scanner, is not available.

In the aforementioned study on the Maya vault, the survey of a part of the sample by digital photogrammetry allowed to obtain detailed 3D models with a high-quality photographic texture that were used to measure, draw, analyze and compare the constructive characteristics of the vaults in detail.

\subsection{Field data collection}

Data collection for the digital documentation of the vaults was organized in two phases: the photogrammetric survey and a direct survey.

For each vault, several photographic sets in raw format were acquired from different angles and heights, using a Nikon D5300 reflex camera and a Nikkor 18-105 VR lens (figure 2). Adjacent photographs were taken with a minimum overlap of $60 \%$ to facilitate subsequent alignment. As seen in figure 3, in each of the sets and every time the daylight conditions changed, we included a color checker chart or a gray card in the scene so that we could later balance and homogenize the chromatic data of the photographs (Russo, 2017).

and spatial reference; on the other hand, the photogrammetric model provides the photographic texture (Gilabert, 2018a; Vidal et al., 2017).
When it is possible to integrate photogrammetric surveying with laser scanner surveying, the advantages of both methods can be exploited: on the one hand, the laser scanner model provides the metric accuracy 


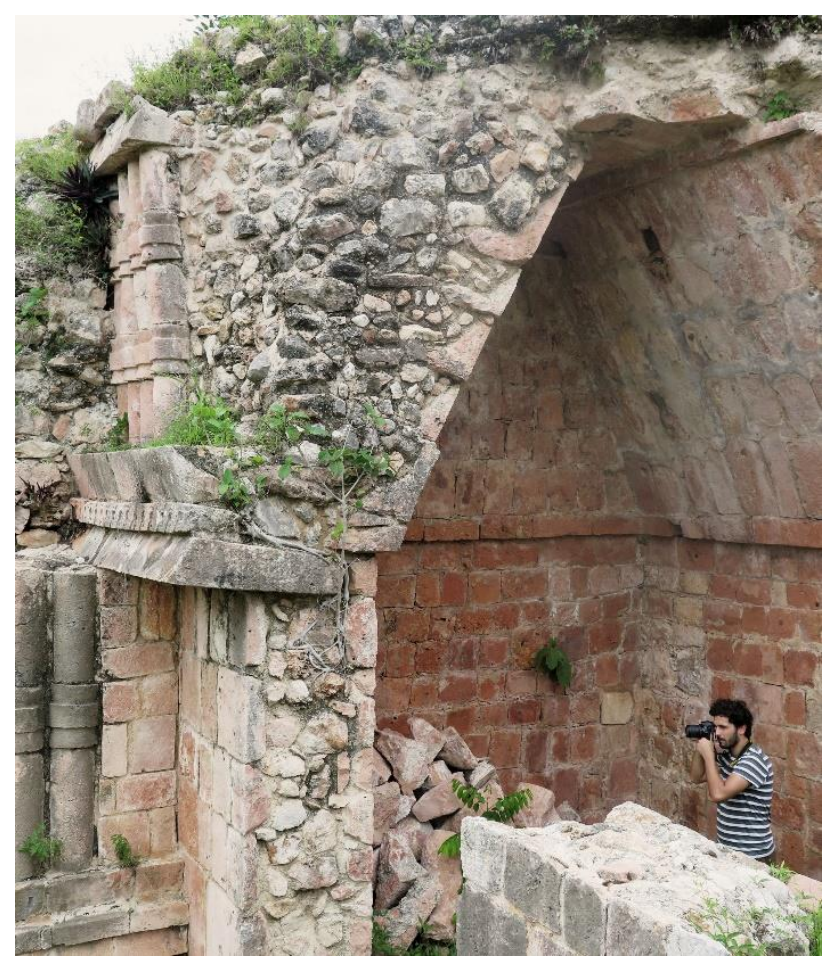

Figure 2. Field data collection in the archaeological site of Chacmultun (Yucatan, Mexico).

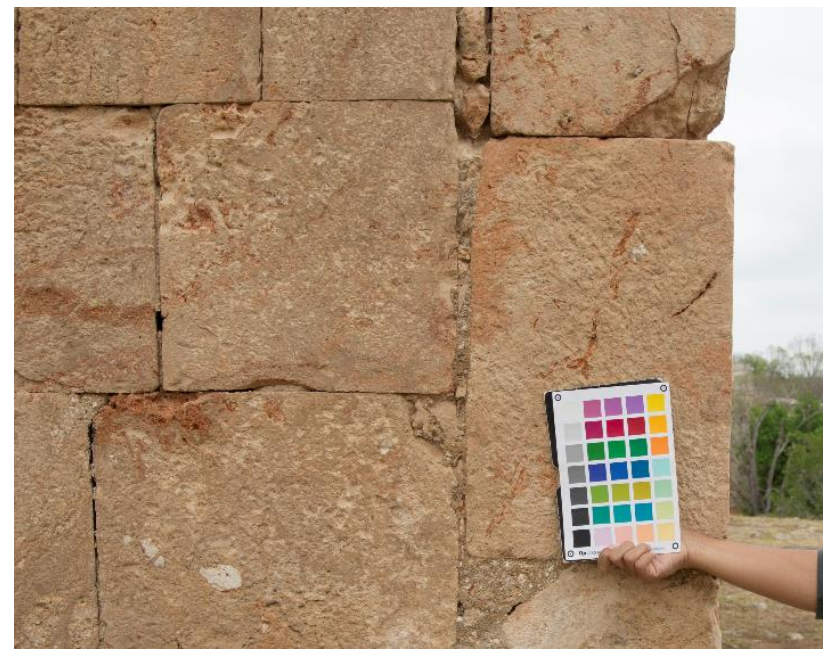

Figure 3. Using a color checker chart during the photogrammetric survey in Uxmal.

Complementary to the photogrammetric survey, we recorded some direct measurements to later scale and orientate the digital model. For this purpose, we located a horizontal reference plane using a laser level and placed several targets on it that were included in the photographic sets for further identification in the digital model. Afterwards, the distances between these reference points were registered in handmade sketches. Finally, in order to avoid these paper targets when calculating the model texture, we carried out an extra set of photographs without them.

In cases where the vaulted ceiling was entirely preserved, the interior rooms were dark spaces, requiring the use of a tripod or a battery-powered LED panel placed on top of the camera.

\subsection{Data processing}

After each field campaign, in a later stage of desk-based work, all the photographic sets were processed with the Agisoft Photoscan digital photogrammetry software. Through the workflow shown in figure 4 , we obtained a highly detailed polygon mesh with photographic texture for each of the vaults (Montuori, Gilabert, 2018). Once the 3D model was calculated, the data from the direct survey were added: each reference point was individualized in the mesh by placing a marker, and measurements taken in situ were introduced in the digital model to orientate and scale it. As a result, a real-scale and chromatically true-to-reality model was obtained for each of the vaults (Figure 5).

These 3D models were very useful to document the vaults and allowed to obtain scaled orthophotos to measure, draw and thoroughly analyze their geometry and constructive details. The main outputs used in this study were the orthophotos of the longitudinal and transversal sections of each vaulted room. However, these high-quality 3D models (figure 5) can have numerous other uses in terms of heritage analysis and dissemination, for instance through virtual reality applications or 3D printing (Montuori, 2018).

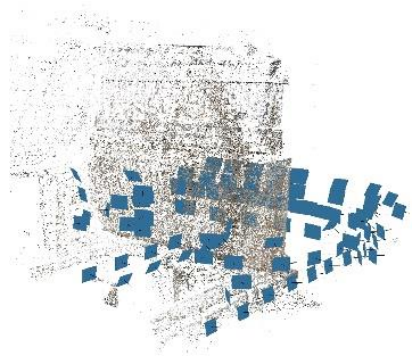

01 Photo alignment

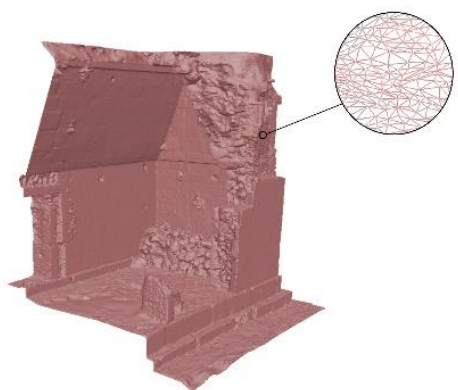

03 High-poly mesh

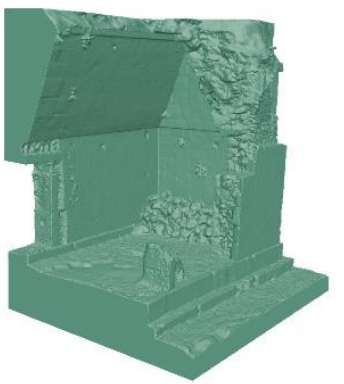

05 3D model integration

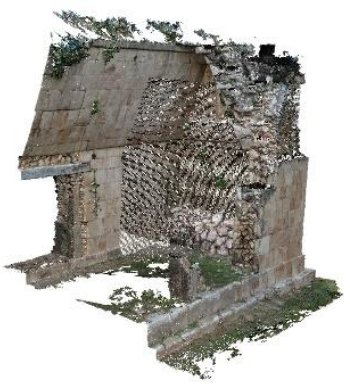

02 Dense point cloud

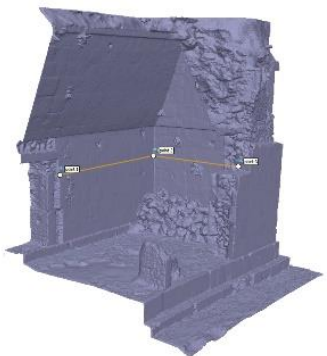

04 Real-scale model

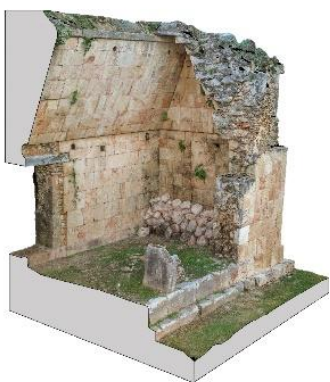

06 Textured model
Figure 4. Modeling of a Maya vault from photogrammetric survey. 


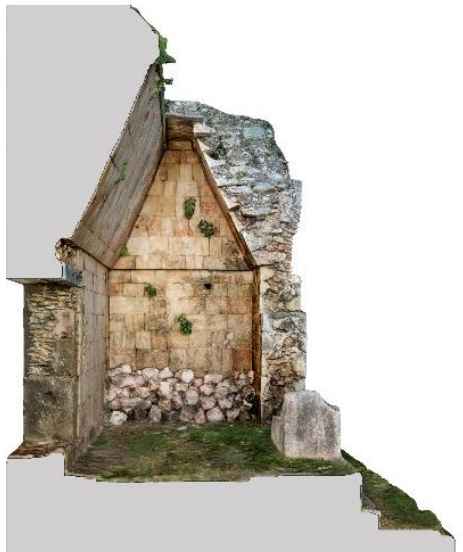

House of the Turtles of Uxmal

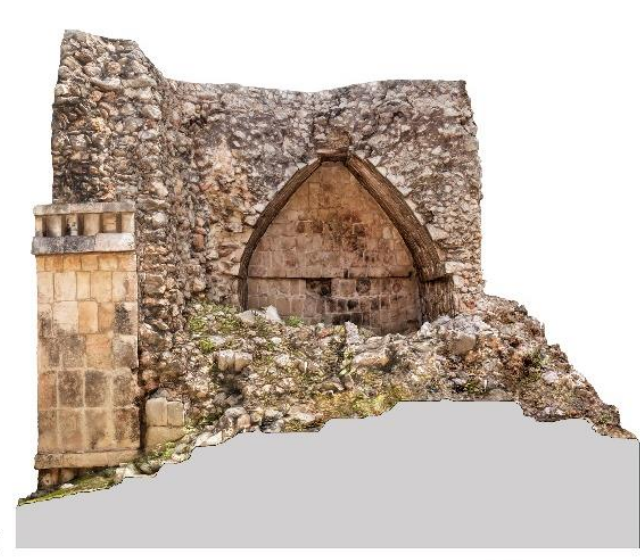

Palace of Xlapak

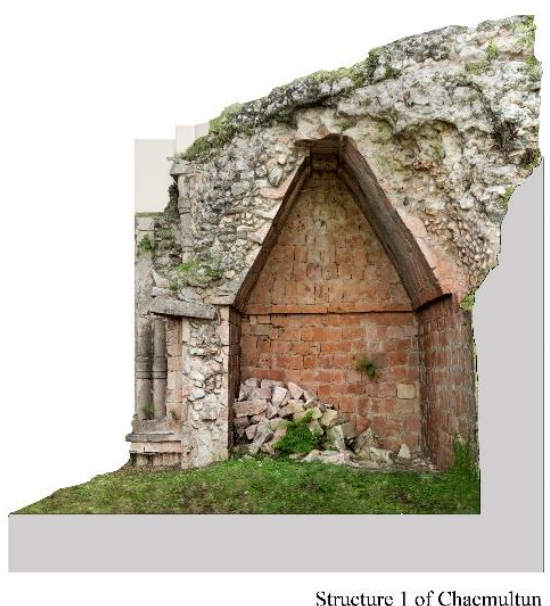

Structure 1 of Chacmultun

Figure 5. 3D models of three Puuc vaults obtained from the photogrammetric surveys.

\section{CASE STUDY: THE HOUSE OF THE TURTLES OF UXMAL}

As an example of the constructive analysis performed from the photogrammetric survey, the case of the House of the Turtles of the archaeological site of Uxmal in Yucatan (Mexico) is presented below.

Included in the World Heritage List of UNESCO since 1996, Uxmal is the most outstanding Maya city in the Puuc region. Known by the exquisite decorations of carved stone mosaics on its buildings, this city represents the pinnacle of late Puuc architecture due to the formal innovations, the large spaces achieved and the constructive quality of its buildings (Gendrop, 1983). In fact, the most advanced Classic Puuc buildings have been classified in a style called Late Uxmal (Andrews, 1995).

The House of the Turtles is a well-known building situated near the northwest corner of the Governor's Palace platform and named after the turtles sculptured in stone decorating the upper molding of its façade (Figure 6). It is a seven-vaulted room palace (Figure 7) classified as Classic Puuc Colonnette style (Andrews, 1995) due to the half-round columnar forms' decoration of its frieze (Figures 6 and 7). Buildings in this style are normally considered to be the earliest in the Classical Period of Puuc architecture (770 - 1.050 CE).

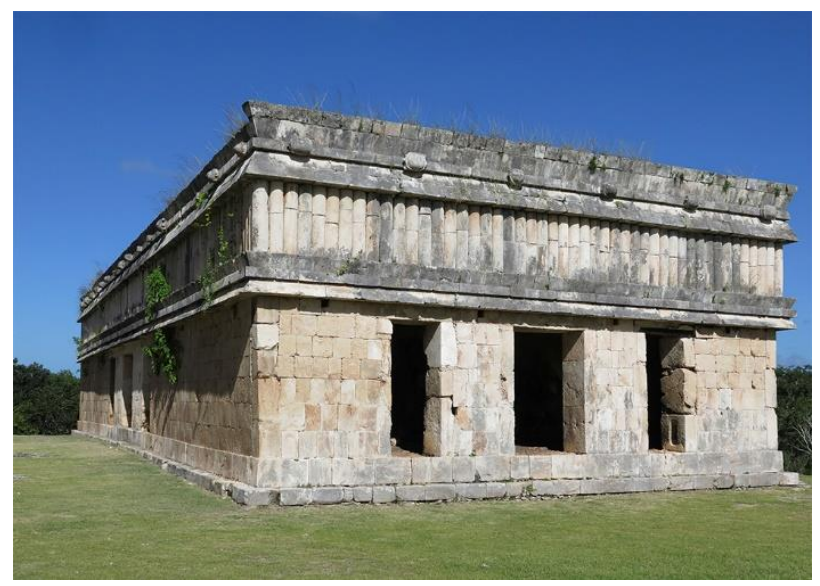

Figure 6. House of the Turtles of Uxmal.
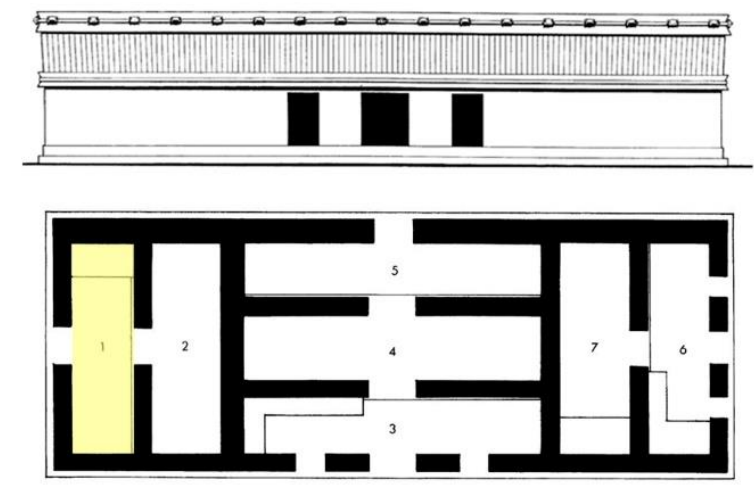

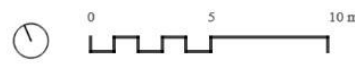

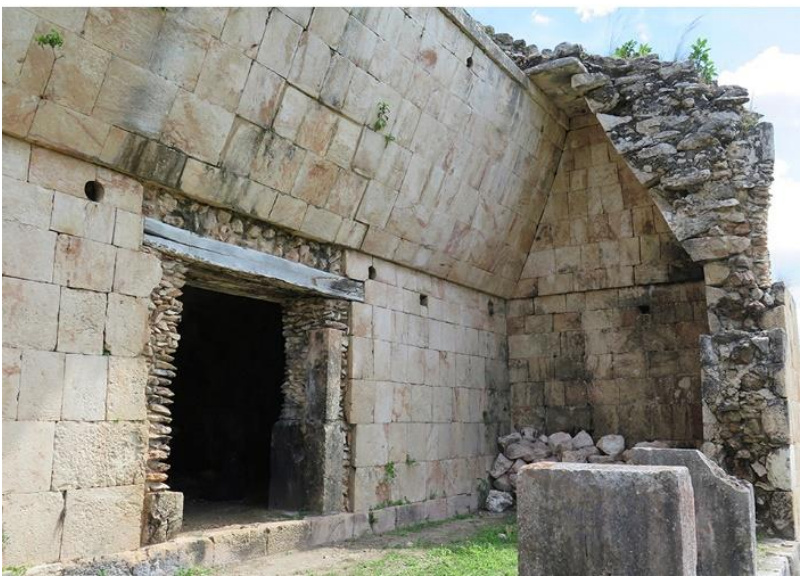

Figure 7. Plan and south elevation of the House of the Turtles by G. Andrews (1993) and north-west view of room 1.

During the field data collection performed in 2016, we registered the geometrical and constructive features of all the vaults of this building by filling in the corresponding registration forms. Additionally, we surveyed room 1 with digital photogrammetry. This room was selected for its unrestored vault, which is still partially collapsed (Figure 7). On the one hand, this allowed us to document a constructive section of the building and, on the other hand, the presence of natural light facilitated photographic data collection. 

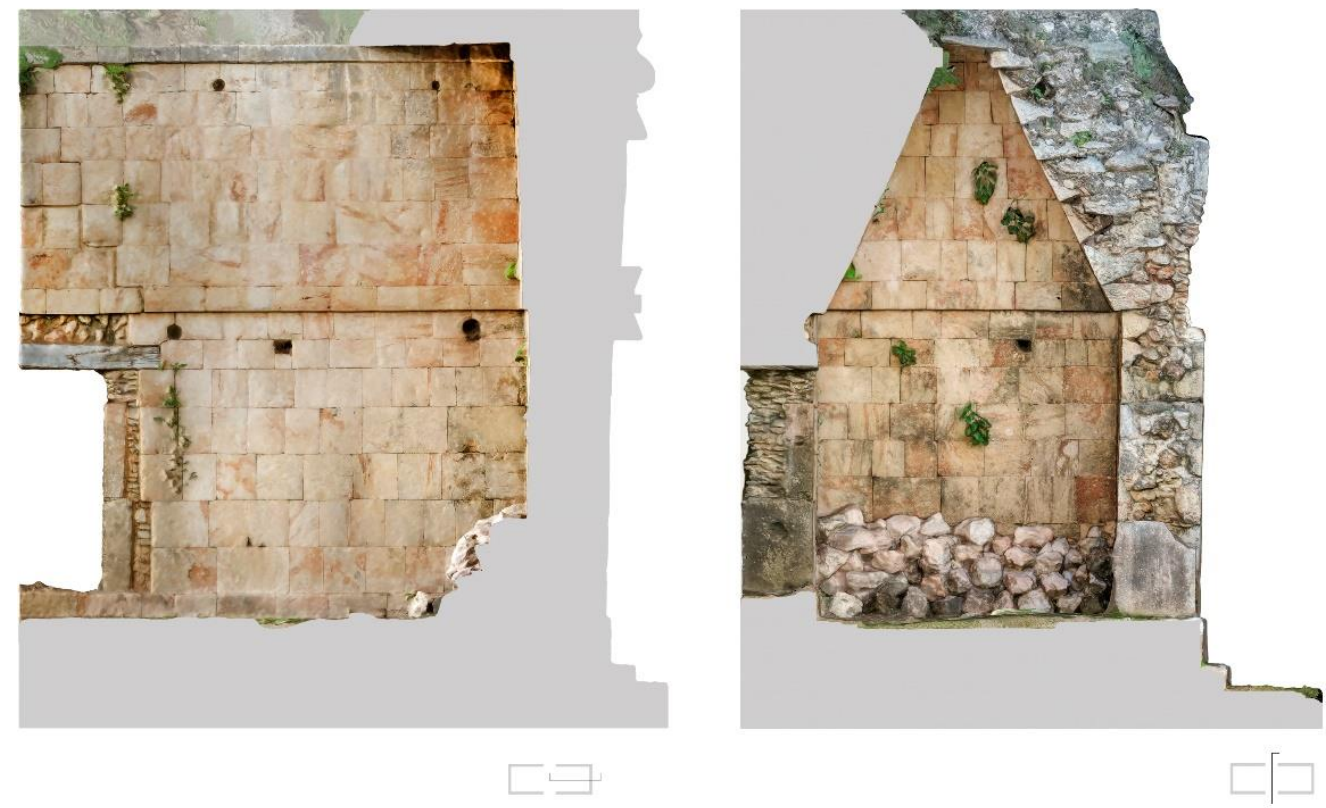

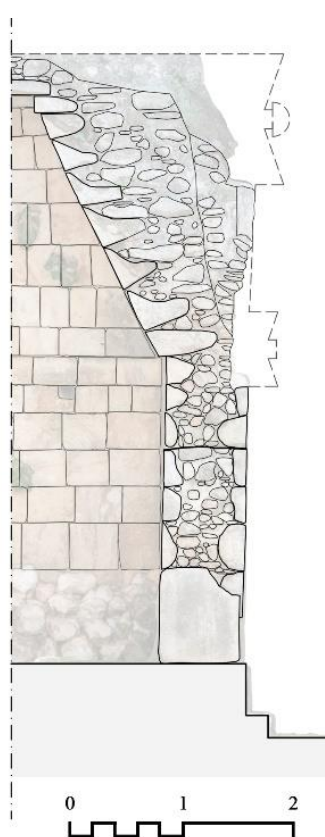

Figure 8. Scaled orthophotos and constructive section of room 1 of the House of the Turtles obtained from the photogrammetric model.
This vaulted room was surveyed with a total of 123 photographs. As mentioned before, we used a color checker chart during data collection to balance and correct the color in the photographs (Figure 3). After obtaining the real-scale digital model of the vault according to the procedure illustrated in figure 4, we exported scaled orthophotos of longitudinal and transversal sections of room 1 (Figure 8). These sections were used as a graphic support for the constructive analysis, the main results of which are shown below.

\subsection{Constructive analysis}

Room 1 measures $9.03 \mathrm{~m}$ long, $2.68 \mathrm{~m}$ wide and has an interior height of $5.00 \mathrm{~m}$ from floor to bottom of capstones. It has two opposite doorways, $1.50 \mathrm{~m}$ wide, in the middle of the long sides of the room, which is usually the most common access configuration in Maya architecture (De Pierrebourg, 2014). Lintels over doorways were made of several square wooden beams, so the original ones have not been preserved. A $20 \mathrm{~cm}$ high step leads into the rear room, which is also a common feature in Maya buildings with several parallel rooms.

There is a bench in the north end of the room and the space is covered by a straight sides vault with a slope of 64 degrees above the horizontal. It springs at $2.75 \mathrm{~m}$ high from floor with a small overhang between 6 and $7 \mathrm{~cm}$. The vault is topped by a row of very carefully cut rectangular corbels $15 \mathrm{~cm}$ high placed just below capstones, which close the vaulted space covering a span of $46 \mathrm{~cm}$ (Figure 8).

4.1.1 Stonework: Vertical walls of the building are constructed with a core of stone rubble and lime mortar, and are faced with relatively thin dressed ashlars, as is characteristic of Classic Puuc buildings ${ }^{2}$. Walls are $70 \mathrm{~cm}$ thick and made up of seven even courses of well-cut squared stones with rounded backs. Doorjambs are formed with large, well-cut and dressed slabs, each of which runs the full thickness of the wall (Figure 8).
The vaulted ceiling is also built with a filling core and faced with finely cut, fitted, specialized wedge-shaped stones with a tenon on the back. As seen in figure 8, on the top of the walls the vault springs with a course of heavier, more deeply tenoned rectangular stones than the higher courses. The rest of facing stones approach the form of an "L", which is the typical vault stones shape of the latest Puuc buildings, commonly known as boot-shaped vault stones (Gilabert, 2020). Their exposed faces are very smoothly dressed with sharp borders and perfectly squared corners, so that the joints between them result in very straight and thin lines.

As illustrated in figure 8 , both the wall ashlars and the vault stones are neatly squared and laid in very even courses. The resulting surfaces are so carefully dressed that only a thin layer of plaster would have been required to achieve an extremely smooth finished surface.

4.1.2 End-vaults formal and constructive analysis was a novel aspect of this study (Gilabert, 2018b). These short sides of the vaults have peculiarities and specific characteristics in each Maya architectural style, and their constructive features influence the process of structural decay of the buildings. Their study is very interesting because it provides information about the construction process of the buildings.

In Classic Puuc structures, end-vaults generally rise from a small overhang at the level of the vault springline. They usually approach the vertical line but lean slightly inward (Pollock, 1980). The photogrammetric survey of some vaults allowed us to exactly measure the slope of these end-vaults. This inclination, sometimes very close to the vertical, cannot normally be detected by direct observation. However, from the longitudinal section of the digital models it was possible to detect it and measure it accurately.

\footnotetext{
2 This type of wall construction has commonly been referred to as "veneer masonry" (Andrews, 1995; Pollock, 1980).
} 
In the House of the Turtles, the end-vaults are leaned two degrees inward from the vertical (Figure 8). Like the half-vaults -the long sides of the vault-, the end-vaults spring with a first course of rectangular blocks that resolve the support on the vertical walls. Above this level, end-vaults are built with an interior core of filling faced with thin squared stones.

4.1.3 Construction process: Having a digital survey allowed us to better analyze the construction aspects of the vaults and to formulate hypotheses on the construction process of these buildings, considering its implications for stability and conservation.

From the examination of the photogrammetric model of the House of the Turtles, we were able to identify and draw two clearly differentiated parts in the rear filling of the vault (figure 8). This shows that the vault was completed before the upper façade masonry was put in place, thus creating a dry joint in the masonry that has caused the partial fall of the frieze ${ }^{3}$. The photogrammetric survey allowed us to precisely quantify the volume of filling built during the construction phase of the vaults. This made it possible to calculate the stability of the structure when the building was in an intermediate phase of construction and had not yet been completed (Gilabert, 2018b).

From the coincidence in the height of the rows of stones in halfvaults and end-vaults we deduced that each row on all four sides of the vault had been built at the same time. To build this type of vaults a centering had probably been needed, on the one hand, to support the facing stones and, on the other hand, to hold the structure up until the lime mortar fillings had stiffened, hardened and gained sufficient strength. In this sense, the analysis of the remains of wooden vault beams (Figure 9) is crucial, inasmuch as they probably played an important role as auxiliary means during the construction process of the building, as we will see below.

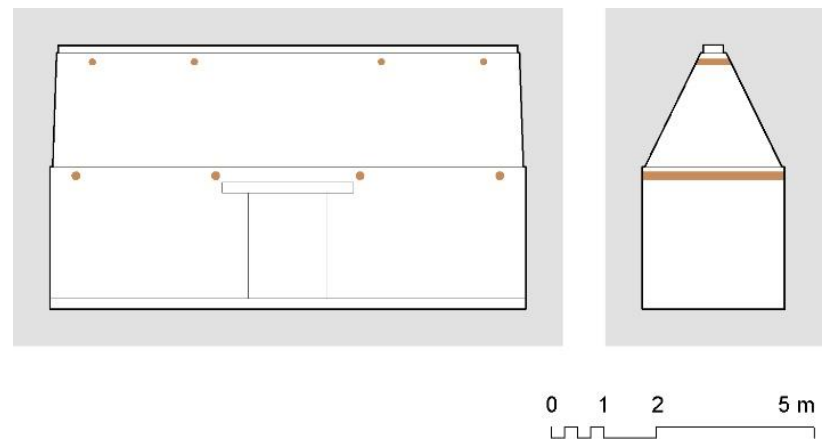

Figure 9. Vault beams diagram of room 1 of the House of the Turtles.

4.1.4 Vault beams are another topic of interest in the investigation on the Maya vault. They are wooden logs that crossed the rooms transversely in several rows placed at different heights, and their function seems to be related to the falsework used during the construction process of the buildings (Gilabert, Peiró, 2019). Being of a perishable material, most vault beams have disappeared and nowadays only the holes where they were embedded remain.
Once again, for vaults case study in which we had a photogrammetric survey, the task of documenting the vault beams remains was more efficient and precise. In the case of the House of the Turtles, vault beams holes are rounded and distributed in two rows: one located in the upper part of the wall, just below the vault springline, and the highest, with smaller diameter holes, is located below the corbels under the capstones, as shown in figure 9 .

\section{DISCUSSION}

The results of the constructive analysis of the House of the Turtles performed from the photogrammetric survey suggest that the construction technology of this building does not correspond to the architectural style traditionally assigned to it.

Due to the decoration of its frieze, consisting of half-round columnar forms, the building is assigned to the Colonnette style (Andrews, 1995), which is considered to be the most primitive stage of the Classical Period of Puuc architecture. However, if we consider its construction technology, taking into account the high quality of stonework seen in both the walls and the vaults, the finish of the stone surfaces, as well as the formal and constructive perfection achieved, it becomes clear that it corresponds to a later stage $^{4}$.

The stonemasonry quality and the vault technology of the building can be favorably compared with those seen in near buildings as the Governor's Palace or the North, East and West wings of the Nunnery Quadrangle, assigned to Late Uxmal style (Andrews, 1995) and considered to be of a later stage than the Colonnette and Mosaic style buildings. Therefore, we consider that the House of the Turtles would very possibly belong to this later period, when Classic Puuc construction technology reached its peak of perfection.

\section{CONCLUSIONS}

Surveying some examples of Maya vaults with digital photogrammetry proved to be a very practical methodology to thoroughly analyze the constructive features of the vaulted buildings. This technique allows to obtain advanced models with affordable instruments and a relatively easy-to-learn procedure, making it an advantageous low-cost tool for effective documentation and digital analysis of architectural heritage.

For most of the vaults included in our study, we manually recorded general measurements in plan and section and characterized formal and constructive features from direct observation. However, in the cases where we performed a photogrammetric survey, we obtained geometrically accurate models with a high-quality photographic texture, from which we were able to extract considerably more information than that extracted from observation and direct surveys.

From the examination of the scaled orthophotos, slopes and deformations that otherwise were invisible to the eye could be detected, quantified and measured. Having such more precise and detailed graphic documentation allows to go further in the constructive analysis of the buildings. In the case of the House of the Turtles of Uxmal, the results of the constructive study have made it possible to formulate a new hypothesis about its architectural style and chronological dating.
3 This has occurred in countless Classic Puuc building façades (Prem, 1995).
4 Although it is no reasonable to date an individual building on the basis of stonework technique, constructive analysis can be one of several indicators of relative age of buildings. 


\section{ACKNOWLEDGEMENTS}

This work was funded by the Spanish Ministry of Science, Innovation and Universities through the Aid Program for pre-doc contracts for training of doctors (ref. BES-2015-071296); by the Universitat Politècnica de València through the Research and Development Grants Program (PAID-01-17) and by Generalitat Valenciana through the Santiago Grisolía grants Program (GRISOLIAP/2018/139). The study is part of the research project Arquitectura Maya: Sistemas Constructivos, Estética Formal, Simbolismo y Nuevas Tecnologías (PGC2018-098904-B-C21$\mathrm{AR})$, funded by the Spanish Ministry of Science, Innovation and Universities.

\section{REFERENCES}

Andrews, G.F., 1993. Architectural survey at Uxmal. George F. and Geraldine D. Andrews papers. Austin: Alexander Architectural Archive, University of Texas.

Andrews, G.F., 1995. Architecture of the Puuc Region and the Northern Plains Area. Pyramids and Palaces, Monsters and Masks. The Golden Age of Maya Architecture, vol. I. Lancaster: Labyrinthos.

De Pierrebourg, F., 2014. Umbral. In (F. De Pierrebourg, M. Humberto Ruz, eds.) Nah, otoch. Concepción, factura y atributos de la morada maya, p. 7-20. Mexico: Instituto de Investigaciones Filológicas de la Universidad Nacional Autónoma de México.

Gendrop, P., 1983. Los estilos Río Bec, Chenes y Puuc. Mexico: Universidad Nacional Autónoma de México.

Gilabert Sansalvador, L., 2018a. Análisis constructivo de la arquitectura maya a través del levantamiento digital. In (L. Agudo, C. Duarte, A. García, J.M. Geiling, A. Higuero, S. Núñez de la Fuente, F.J. Rodríguez, R. Suárez, eds.) Actas de las IX Jornadas de Jóvenes en Investigación Arqueológica, 65-70. Santander: Instituto Internacional de Investigaciones Prehistóricas de Cantabria.

Gilabert Sansalvador, L., 2018b. La bóveda en la arquitectura maya. Doctoral thesis. Universitat Politècnica de València.

Gilabert Sansalvador, L., 2020. La evolución de la bóveda maya a través de la forma de las dovelas. Estudios de Cultura Maya, 55, 65-87. doi.org/10.19130/iifl.ecm.55.2020.0003.

Gilabert Sansalvador, L., Peiró Vitoria, A., 2019. Los morillos como estructura auxiliar en el proceso constructivo de las bóvedas mayas. In (I. del Cueto, V.M. Méndez, S. Huerta, eds.) Actas del Tercer Congreso Internacional Hispanoamericano de Historia de la Construcción, vol. I, p. 421-430. Madrid: Instituto Juan de Herrera.

Hohmann, H., 1979. Gewölbekonstruktionen in der MayaArchitektur. Mexicon, I (3), p. 33-36.

Merlo, A., Aliperta, A., 2015. Levantamiento digital y modelación 3D. Firenze: Dipartamento di Architettura. Università degli Studi di Firenze.

Montuori, R., 2018. Modelado e impresión 3D de ruinas arqueológicas: el caso de la Acrópolis de La Blanca. In (L. Agudo, C. Duarte, A. García, J.M. Geiling, A. Higuero, S. Núñez de la Fuente, F.J. Rodríguez, R. Suárez, eds.) Actas de las IX
Jornadas de Jóvenes en Investigación Arqueológica, p. 71-79. Santander: Instituto Internacional de Investigaciones Prehistóricas de Cantabria.

Montuori, R., Gilabert Sansalvador, L., 2018. Documentación y estudio comparativo de cuatro bóvedas mayas del área Puuc. In (R. Llamas Pacheco, J.L. Alapont Ramón, eds.) EMERGE 2018 Jornadas de Investigación Emergente en Conservación y Restauración de Patrimonio, p. 79-88. Valencia: Universitat Politècnica de València.

Pollock, H.E.D., 1980. The Puuc. An architectural survey of the hill country of Yucatan and Northern Campeche, Mexico. Cambridge, Massachusetts: Peabody Museum of Archaeology and Ethnology, Harvard University.

Prem, H.J., 1995. Consideraciones sobre la técnica constructiva de la arquitectura Puuc. Cuadernos de Arquitectura Mesoamericana, 29, 29-38.

Remondino, F., 2014. Photogrammetry. In (F. Remondino, S. Campana, eds.) $3 D$ recording and modelling in archaeology and cultural heritage: theory and best practices, p. 65-87. BAR International Series 2598.

Russo, M., 2017. Il ruolo del colore nella conoscenza dei Beni Archeologici. In (V. Marchiafava, F. Valan, eds.) Colore $e$ Colorimetria. Atti della Tredicesima Conferenza del Colore, 405-416. Napoli: Gruppo del Colore, Associazione Italiana Colore.

Russo, M., Manfredini, A.M., 2014. Metodiche integrate di rilievo 3D per l'analisi di architetture complesse. Il caso dell'Abbazia di Pomposa. In (P. Giandebiaggi, C. Vernizzi, eds.) Atti del $36^{\circ}$ Convegno internazionale dei docenti della rappresentazione, 989-998. Parma: Gangemi Editore.

Vidal Lorenzo, C., Muñoz Cosme, G., Merlo, A., 2017. Surveying Ancient Maya Buildings in the Forest. In (A. Ippolito, ed.) Handbook of Research on Emerging Technologies for Architectural and Archaeological Heritage, p. 255-290. Hershey PA: IGI Global. 